BNL 50854

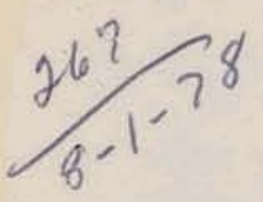

\title{
SOLIDIFICATION OF SIMULATED TRANSURANIC CONTAMINATED INCINERATOR ASH WASTES USING PORTLAND TYPE I CEMENT
}

R.M. Neilson, Jr. and P. Colombo

\section{MASTER}

\section{MAY 1978}

Prepared under Subcontract with

BATTELLE PACIFIC NORTHWEST LABORATORIES

for the

UNITED STATES DEPARTMENT OF ENERGY

NUCLEAR WASTE MANAGEMENT RESEARCH GROUP

DEPARTMENT OF NUCLEAR ENERGY

BROOKHAVEN NATIONAL LABORATORY

ASSOCIATED UNIVERSITIES, INC.

UNDER CONTRACT NO. EY-76-C-02-0016 WITH THE

UNITED STATES DEPARTMENT OF ENERGY 


\section{DISCLAIMER}

This report was prepared as an account of work sponsored by an agency of the United States Government. Neither the United States Government nor any agency Thereof, nor any of their employees, makes any warranty, express or implied, or assumes any legal liability or responsibility for the accuracy, completeness, or usefulness of any information, apparatus, product, or process disclosed, or represents that its use would not infringe privately owned rights. Reference herein to any specific commercial product, process, or service by trade name, trademark, manufacturer, or otherwise does not necessarily constitute or imply its endorsement, recommendation, or favoring by the United States Government or any agency thereof. The views and opinions of authors expressed herein do not necessarily state or reflect those of the United States Government or any agency thereof. 


\section{DISCLAIMER}

Portions of this document may be illegible in electronic image products. Images are produced from the best available original document. 


\title{
SOLIDIFICATION OF SIMULATED TRANSURANIC CONTAMINATED INCINERATOR ASH WASTES USING PORTLAND TYPE I CEMENT
}

\author{
R.M. Neilson, Jr. and P. Colombo
}

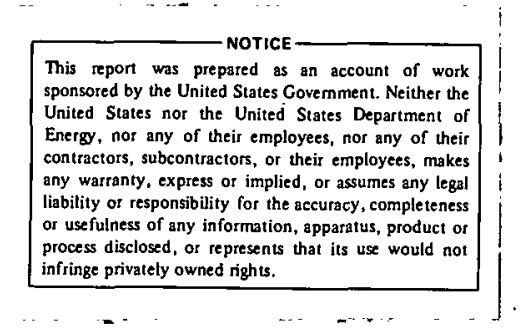

\section{MAY 1978}

\author{
Prepared under Subcontract with \\ BATTELLE PACIFIC NORTHWEST LABORATORIES \\ for the \\ UNITED STATES DEPARTMENT OF ENERGY
}

\section{NUCLEAR WASTE MANAGEMENT RESEARCH GROUP DEPARTMENT OF NUCLEAR ENERGY}

BROOKHAVEN NATIONAL LABORATORY UPTON, NEW YORK 11973 


\section{NOTICE}

This report was prepared as an account of work sponsored by the United States Government. Neither the United States nor the United States Department of Energy (DOE), nor any of their employees, nor any of their contractors, subcontractors, or lieir employees, makes any warranty, express or implied, or assumes any legal liability or responsibility for the accuracy, completeness or usefulness of any information, apparatus, product or process disclosed, or represents that its use would not infringe privately owned rights.

Printed in the United States of America

$$
\text { Available from }
$$

National Technical Information Service

U.S. Department of Commerce

5285 Port Royal Road

Springfield, VA 22161

Price: Printed Copy $\$ 4.00$; Microfiche $\$ 3.00$

June 1978

355 copies 


\section{Table of Contents}

\section{$\underline{\text { Page }}$}

Surmary

iv

1. Introduction

2. Solidification of TRU Incinerator Ash

2.1 Incinerator Ash Compositions..

2.2 Compositional Phase Fields for TRU Ash Solidification. . 3

2.2.1 Minimum Workability

2.2.2 Maximum Water

2.2.3 Minimum Set Time

2.2.4 Compressive Strength

\section{List of Tables}

1. Battelle Northwest TRU Incinerator Ash 4

2. Rocky Flats Plutonium Recýcle TRU Ash 5

3. Mound Laboratory Cyclone Incinerator TRU Ash $11 \mathrm{~A}^{2} \quad 6$

4. Set Time Determinations Using the Vicat Needle Method (ASTM C 191-74)

5. Compressive Strength of Solidified Waste Forms (Seven-Day Cure Time)

\section{List of Figures}

1. Compositional Phase Field for BNW TRU Incinerator A'sh Portland Type I Cement waste Forms

2. Compositional Phase Field for Rocky Flats Plutonium Recycle TRU Ash - Portland Type I Cement Waste Forms

3. Compositional Phase Field for Mound Incinerator TRU Ash $11 \mathrm{~A}^{2}-$ Portland Type I Cement Waste Forms. 
A preliminary study was performed to investigate the use of hydraulic cement for the solidification of transuranic (TRU) contaminated incinerator ash wastes. In this work, the compositional phase fields in which acceptable solidification is obtained using portland type I cement were determined for three simulated TRU incinerator ash wastes. These wastes include Battelle Northwest TRU incinerator ash, Rocky Flats plutonium recycle TRU incinerator ash, and Mound Laboratory cyclone incinerator TRU ash $11 \mathrm{~A}^{2}$. The compressive strengths and set times of selected formulations were measured. 


\section{Introduction}

Considerable quantities of transuranic (TRU) contaminated wastes are stored or buried at various DOE sites. Ultimately these wastes will be removed and placed into a geologic repository for disposal. While there is some question as to whether existing TRU wastes will be disposed in their current form or first undergo some additional volume reduction process, it is evident that volume reduction will be required for future TRU wastes. Incineration is the primary candidate for the volume reduction of combustible TRU wastes, however, the ash that results is highly dispersible. The immobilization of the TRU incinerator ash by solidification producing a solid monolithic waste form is therefore desirable.

Hydraulic cement has been the primary agent used at DOE installations for the solidification of TRU, low-level, and intermediate-level radioactive wastes. Therefore, the extension of the use of hydraulic cement for TRU incinerator ash is a natural one. The attributes of hydraulic cement for this purpose include low cost, availability, room temperature solidification, and well known processing technology. However, while hydraulic cement appears to be chemically compatible with TRU incinerator ashes, this compatibility and the compositional ranges over which it exists must be demonstrated.

Incinerator ash wastes are dry wastes and since water is required for hydraulic cement hydration, water must be added. The amount of water added is important since sufficient quantities must be present to form a workable and pourable cement mix. However, the addition of an excessive amount of water can result in the presence of free standing water after solidification. Sufficient cement must be included in the formulation to hold the waste form together producing a free standing monolithic mass. Also, the cement mixture must have a sufficiently long set time to allow complete mixing and transfer from the mixing mechanism to the container in which the mixture is cast.

In this study, the compositional phase fields in which acceptable solidification is obtained using portland type I cement were determined for three simulated TRU incinerator ash wastes. These wastes include Battelle Northwest 
(BNW) TRU incinerator ash, Rocky Flats plutonium recycle TRU incinerator ash and Mound Laboratory cyclone incinerator TRU ash $11 \mathrm{~A}^{2}$. The compressive strengths and set times of selected ash-cement formulations were measured. Portland type I cement was used in this study since it is the most readily available and inexpensive variety of hydraulic cement and because the attributes (low heat of hydration, quick setting, or increased sulfate resistance) of other portland cement types does not appear to be particularly useful for TRU incinerator ash solidification. 


\section{Solidification of TRU Incinerator Ash}

\subsection{Incinerator Ash Compositions}

Three simulated TRU incinerator ashes were used in this study; their compositions are listed in Tables 1-3. These simulated ashes include Battelle Northwest (BNW) TRU incinerator ash, Rocky Flats plutonium recycle TRU ash, . and Mound Laboratory cyclone incinerator TRU ash $11 \mathrm{~A}^{2}$. The simulated ash compositions listed in Tables 1-3 are essentially those suggested by Battelle Northwest. (1) Some substitutions have been made from the original composition in the Rocky flats plutonium recycle TRU ash. Specifically $\mathrm{PbO}_{2}, \mathrm{KOH}, \mathrm{NaOH}$, and $\mathrm{V}_{2} \mathrm{O}_{5}$ have been substituted for $\mathrm{PuO}_{2}, \mathrm{~K}_{2} \mathrm{O}, \mathrm{Na}_{2} \mathrm{O}$, and $\mathrm{Ta}_{2} \mathrm{O}_{5}$ respectively. The carbon used was in the form of animal charcoal powder. These simulated wastes were prepared in one kilogram batches using a jar mill (burundrum grinding medial for concurrent mixing and grinding. It was determined that the simulated waste batches prepared in this manner were homogeneous. Simulated waste batches were stored in sealed containers to minimize water absorption. Storage times were short due to the small waste batches prepared.

\subsection{Compositional Phase Fields for TRU Ash Solidification}

Laboratory studies have determined the compositional phase fields over which each of the incinerator ashes investigated form satisfactory solids when combined with portland type I cement and water. These phase fields were determined by (1) minimum water for sufficient mixture workability, (2) maximum water, and (3) minimum set time. These compositional phase fields have been conservatively determined and are shown in Figures 1-3 for Battelle Northwest (BNW) TRU incinerator ash, Rocky Flats plutonium recycle TRU ash and Mound Laboratory cyclone incinerator TRU ash respectively.

\subsubsection{Minimum Workability}

Sufficient water must be added to any given ash-cement mixture to provide adequate workability during mixing. Good workability is required to provide a homogeneous pourable mixture in a reasonable time using conventional mechanical cement mixing techniques. With insufficient water added, either the cement and/or the ash has a tendency to "ball up" inhibiting 
Table 1

Battelle Northwest TRU Incinerator Ash

\begin{tabular}{lc} 
Material & \multicolumn{2}{c}{ Weight Percentage } \\
\hline $\mathrm{SiO}_{2}$ & 35.8 \\
$\mathrm{TiO}_{2}$ & 17.4 \\
$\mathrm{Al}_{2} \mathrm{O}_{3}$ & 17.8 \\
$\mathrm{CaO}$ & 5.8 \\
$\mathrm{CaCl}_{2}$ & 3.8 \\
$\mathrm{CaSO}_{4}$ & 1.7 \\
$\mathrm{NaCl}_{\mathrm{KCl}}$ & 1.9 \\
$\mathrm{C}$ & 1.4
\end{tabular}

Note: This ash absorbs approximately. 5 percent water by weight. 
Table 2

Rocky Flats Plutonium Recycle TRU Ash

Material

$\mathrm{Al}_{2} \mathrm{O}_{3}$

$\mathrm{BaO}$

$\mathrm{B}_{2} \mathrm{O}_{3}$

$\mathrm{CaO}$

$\mathrm{Cr}_{2} \mathrm{O}_{3}$

Cuo

$\mathrm{Fe}_{2} \mathrm{O}_{3}$

$\mathrm{PbO}$

Mgo

$\mathrm{MnO}_{2}$

NiO

$\mathrm{P}_{2} \mathrm{O}_{5}$

$\mathrm{KOH}$

$\mathrm{PbO}_{2}$

$\mathrm{SiO}_{2}$

$\mathrm{NaOH}$

$\mathrm{V}_{2} \mathrm{O}_{5}$

SnO

$\mathrm{TiO}_{2}$

C
Weight Percentage

3.69

0.59

1.67

3.64

2.36

0.64

5.85

0.54

2.90

0.10

0.50

0.59

0.50

2.61

45.00

0.89

0.64

0.15

2.17

25.00 
Table 3

Mound Laboratory Cyclone Incinerator TRU Ash $11 \mathrm{~A}^{2}$

\begin{tabular}{lc} 
Material & Weight Percentage \\
\cline { 2 - 2 } $\mathrm{SiO}_{2}$ & 30.52 \\
$\mathrm{Al}_{2} \mathrm{O}_{3}$ & 32.72 \\
$\mathrm{CaO}$ & 6.22 \\
$\mathrm{Fe}_{2} \mathrm{O}_{3}$ & 4.98 \\
$\mathrm{MgO}$ & 8.22 \\
$\mathrm{Cr}_{2} \mathrm{O}_{3}$ & 2.54 \\
$\mathrm{TiO}_{2}$ & 5.80 \\
$\mathrm{MoO}_{3}$ & 0.04 \\
$\mathrm{NiO}_{\mathrm{ZnO}}$ & 5.53 \\
$\mathrm{CuO}$ & 3.25 \\
$\mathrm{~B}_{2} \mathrm{O}_{3}$ & 0.11 \\
$\mathrm{SnO}$ & 0.03
\end{tabular}




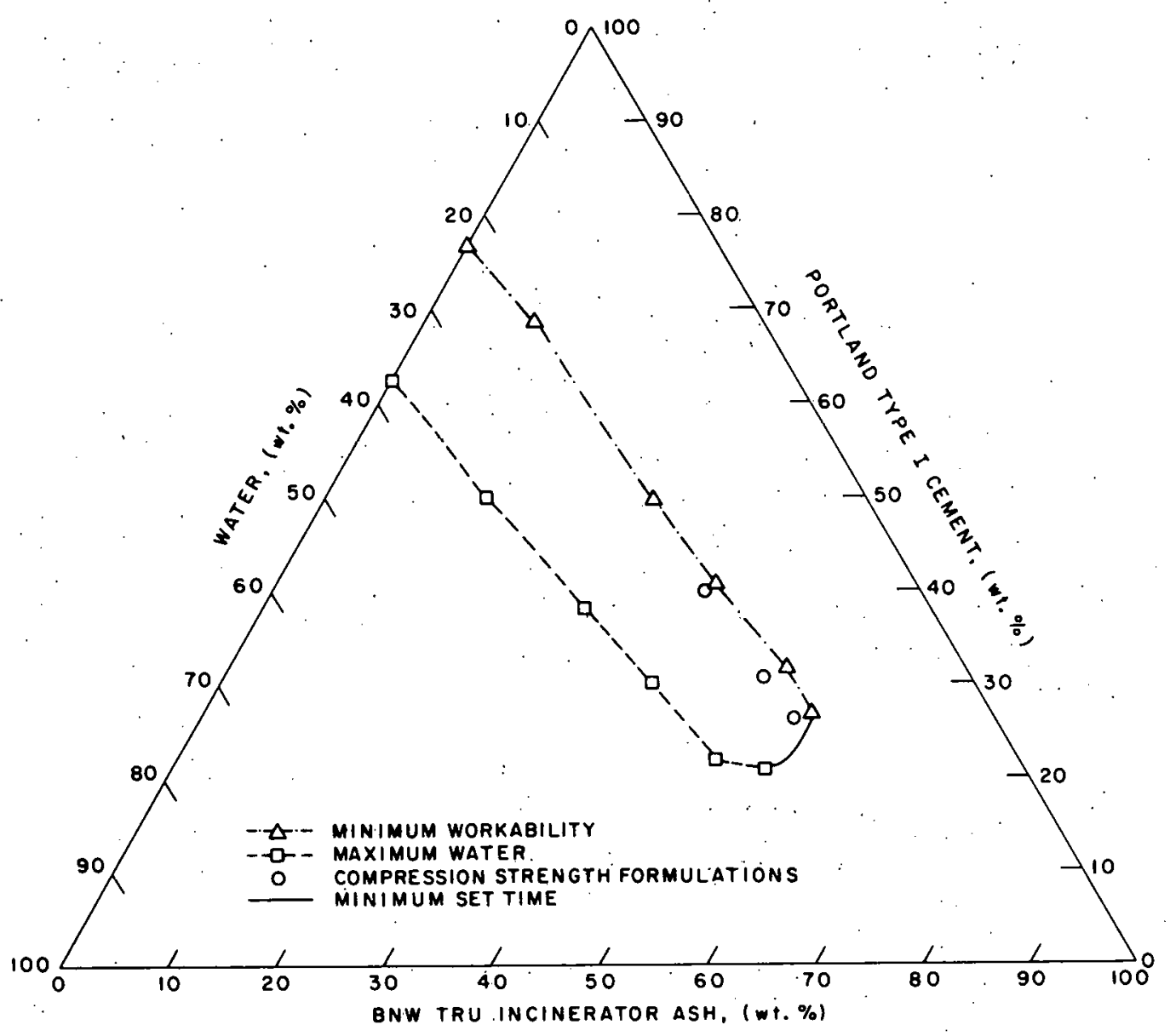

Figure 1. Compositional phase field for BNW TRU incinerator ASH - portland type I cement waste forms. 


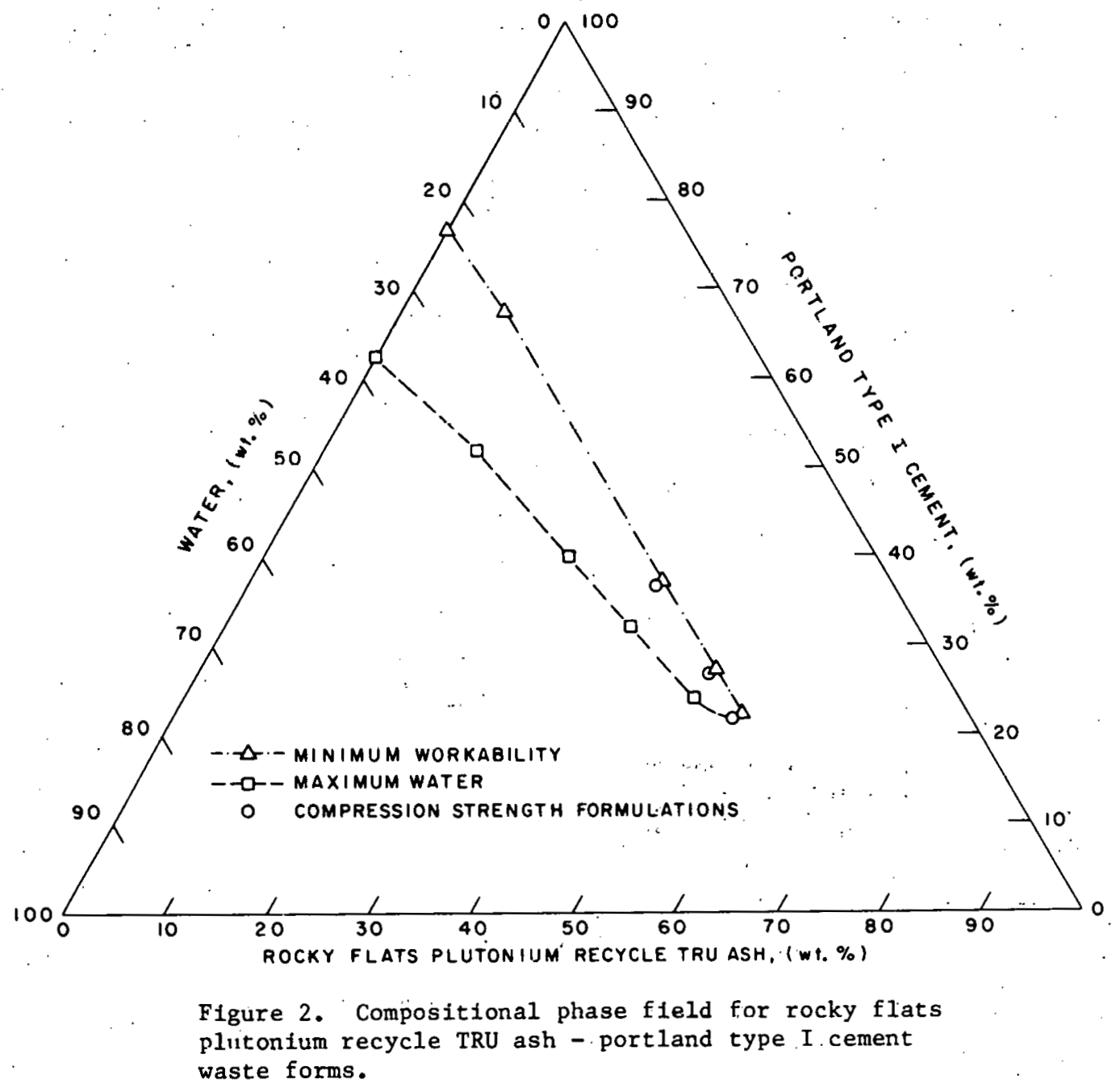




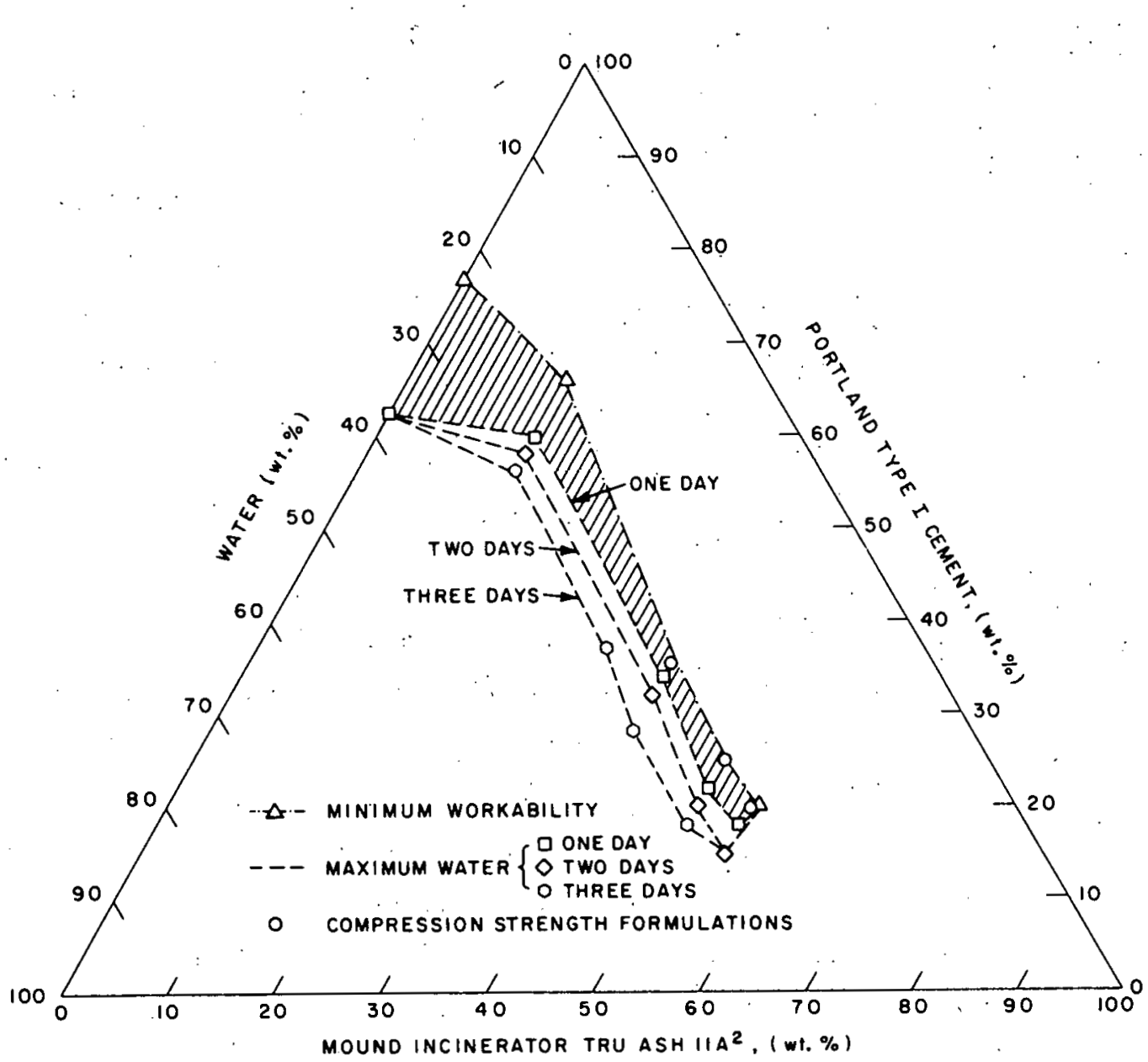

Figure 3. Compositional phase field for mound incinerator TRU ash $11 \mathrm{~A}^{2}$ - portland type I cement waste forms. 
complete mixing and mixture pourability. The amount of water necessary for sufficient workability is a subjective determination since there is no sharp transition and is somewhat dependent on the mixing method employed. A Hobart Model N-50 dough-type mixer was used in this study. The amount of water required has been determined such that somewhat smaller water additions may provide adequate workability; however, the water additions reported here give adequate mixture workability and also produce relatively easy pourable mixes. Since these water additions were conservatively determined, they are expected to be adequate for all conventional mixing techniques reasonably independent of the relationship of workability with mixing technique. Note that pourability is generally the determinative factor since the minimum water addition necessary to provide adequate mixing usually is not sufficient to produce a pourable mixture.

The initial minimum workability formulations were estimated based on experimental determinations of the minimum water to cement $(\mathrm{w} / \mathrm{c})$ weight ratio required for workability of portland type I cement, and the absorptive capacity of the simulated incinerator ashes towards water. The minimum water to cement ratio for portland type I cement was determined by the gradual addition of water to a known mass of cement during mixing. A pourable cement-water mixture was obtained using a water to cement ratio of 0.30 by weight. This corresponds to a mixture containing 23.1 wt. 8 water and 76.9 wt. 8 cement.

The water absorption capacities of the simulated incinerator ashes were determined by taking 50 grams of ash and adding sufficient water to completely immerse the ash. The ash and water mixture was agitated and allowed to equilibrate for approximately one hour, after which time the excess water was poured off. The water absorption of the ash was then expressed as a weight ratio of the absorbed water to the dry ash. By this technique, water to ash ratios of $0.2,0.3$, and 0.35 were determined for water absorption by the Battelle Northwest TRU incinerator ash, Rocky Flats plutonium recycle TRU ash and Mound Laboratory cyclone incinerator TRU ash respectively. 
Initial minimum workability formulations were then estimated based on the experimentally determined water to cement and water to ash ratios. These minimum water formulations are of particular interest because the original waste is dry and little purpose is served by the addition of water to the waste beyond that necessary for mixing and pouring purposes. These compositions were derived by first determining the weight percentage of the ash waste desired in the solidified product and then calculating the amount of water necessary to satisfy the ash water absorption. The remainder of the formulation weight is composed of cement and the water for cement workability which are calculated using the water to cement ratio. The water requirements for ash absorption and cement workability were then added to determine the total water content of the formulation.

The minimum water for workability was then measured experimentally for mixtures containing approximately 15, 30, 40, 50, and 55 weight percent ash. The ash and cement contents of these formulations were taken from those estimated for minimum workability based on the experimentally measured water to cement and water to ash ratios. However, the total ash and cement were dry mixed and subsequently water was added until the mixture obtained good workability during mixing (subjectively equivalent to that of cement at a water to cement ratio of 0.3 ). This quantity of water was measured and used to determine the precise formulation of these minimum workability mixes. These formulations and the line providing the minimum water compositional boundary are shown in Figures 1-3. The experimentally determined minimum water compositions had slightly lower water contents but generally were in good agreement with the estimated minimum water compositions.

\subsubsection{Maximum Water}

The maximum water that can be incorporated in a waste formulation without producing free standing liquid has been determined. Since the incinerator ashes under study are all dry wastes, normally only that quantity of water necessary to provide good workability would be added. However, it is important to know if the phase field is narrow at any particular waste content since this will determine the care which must be taken 
in the addition of the appropriate amount of water. The maximum water boundary, as shown in Figures $1-3$, has been conservatively determined.

The minimum water to cement. weight ratio which results in the first signs of free standing liquid with portland type I. cement was measured. This was accomplished by making mixtures over a range of water to cement weight ratios, each containing 250 grams of cement. The cement and water were combined in a Hobart Model N-50 mixer and the mixture poured into a covered one pint capacity glass jar for setting and curing. The glass jar was covered to prevent evaporative water loss. The cement surface was inspected after twenty-four hours for the presence of free standing water. A few drops of water were first noted at a water to cement weight ratio of 0.60 (62.5 wt. 8 cement, 37.5 wt. $\frac{4}{6}$ water). At higher ratios progressively more free standing liquid was present.

The cement and water contents of formulations of each ash containing 15, 30, 40, 50, and 55 weight percentage ash were varied to determine the maximum water line. Fifty gram samples of each formulation were prepared by hand mixing in which all the water in the formulation was added to the ash prior to the addition of the dry portland type I cement. The small plastic cups in which these formulations were prepared were covered to prevent evaporative water loss. After twenty four hours, each formulation was examined for the presence of free standing water. The presence of free standing water was conservatively determined; a formulation was deemed unacceptable if either free liquid appeared on the surface or if the surface was excessively moist to the touch. This conservative approach was taken because of the small size of the samples (which was dictated by the amount of ash required). As can be seen in Figure 3, the compositional range determined for the Mound Laboratory cyclone incinerator ash $11 \mathrm{~A}^{2}$ was quite narrow for ash contents above 15 wt. $\%$. For this ash, the maximum water samples were also examined after two and three days of curing. This demonstrated a broadening of the acceptable phase field. 


\subsubsection{Minimum Set Time}

The set time of ash-cement-water formulations was investigated using ASTM C 191-74, "Standard Method of Test for Time of Setting of Hydraulic Cement by Vicat Needle". Set time is a measure of the rate at which the cement mix hardens and is of importance since cement mixes should be placed prior to initial setting to prevent hardening in the mixing apparatus (and the maintenance problems which would result) and also because cement mixes disturbed after the initial set generally do not achieve maximum strength characteristics. On the basis of cement mixing technology, it is desirable that cement formulations used have set times of thirty minutes or more to allow ample time for mixing and pouring. ASTM specification C 150-74 requires that the initial set for portland cement not be less than forty-five minutes (Vicat test) to allow mixing and placing. For the incinerator ash solidification application considered here, somewhat shorter set times are acceptable since large mass placings are not envisioned. Alternately, the set time should not be so long that the cement mixture requires excessive time for hardening or never hardens at all.

In the vicat needle method, the depth of penetration of a one millimeter diameter steel needle under 300 grams of load into a cement mix confined in a molding ring is measured as a function of time after mixing. This measurement is taken periodically until the penetration into the cement mix is $25 \mathrm{~mm}$ or less. The time required to achieve a penetration of $25 \mathrm{~mm}$ or less is defined as the set time. Set time measurements were made by this procedure for each of the formulations and a cement control as shown in Table 4. Measurements were made at an average temperature of $24^{\circ} \mathrm{C}$ and a relative humidity of $60 \%$. Testing was begun after the cement formulations had been mixed for five minutes. The formulations utilized were the estimated minimum water formulations determined from the minimum water/cement ratio for workability and the respective water/ash ratios for water absorption. The set times of Battelle Northwest TRU incinerator ash decreased as the ash content was increased, until a set time of forty minutes.was attained for the 55 wt. $\%$ ash formulation. As such, a limit of the amount of this ash that can be incorporated in cement based on set time measurements is believed to exist somewhat 


\section{Table 4 .}

Set Time Determinations Using the Vicat Needle Method (ASTM C 191-74)

\begin{tabular}{|c|c|c|c|c|c|}
\hline Waste type & $\underline{\text { Ash }}$ & Cement & Water & Temperature, ${ }^{\circ} \mathrm{C}$ & $\begin{array}{l}\text { Set time } \\
\text { Minutes } \\
\end{array}$ \\
\hline \multirow[t]{3}{*}{$\mathrm{BNW}$} & 55.0 & 26.2 & 18.8 & 23 & 40 \\
\hline & 50.0 & 30.8 & 19.2 & 25 & 45 \\
\hline & 40.0 & 40.0 & 20.0 & 24 & 85 \\
\hline \multirow{3}{*}{$\begin{array}{l}\text { Rocky } \\
\text { Flats }\end{array}$} & 55.0 & 21.9 & 23.1 & 25 & 100 \\
\hline & 50.0 & 26.9 & 23.1 & 23 & 75. \\
\hline & 40.0 & 36.9 & 23.1 & 25 & 50 \\
\hline \multirow{3}{*}{$\begin{array}{l}\text { Mound } \\
\text { Lab }\end{array}$} & 55.0 & 19.8 & 25.2 & 23 & 195 \\
\hline & 50.0 & 25.0 & 25.0 & 23 & 210 \\
\hline & 40.0 & 35.4 & 24.6 & 22 & 360 \\
\hline Control & - & 76.9 & 23.1 & 22 & 135 \\
\hline
\end{tabular}

(a) After five minutes of mixing. 
above 55 wt. 8 ash. The minimum set time limit was not approached with the other simulated ashes tested. Set time is dependent on the waste composition since the waste may contain materials that can act as either accelerators or retarders towards cement setting. Some compounds can act as either retarders or accelerators depending upon their concentration in the cement mix.

Excessively long set times are undesirable since they are usually indicative of long solidification times. Set times in excess of that measured for the portland cement control were encountered only with Mound Laboratory incinerator ash formulations. However, these set times do not appear to be long enough to present any difficulties.

\subsubsection{Compressive Strength}

The compressive strength of various solidified ash formulations was measured by the method of ASTM C 39-72, "Standard Method of Test for Compressive Strength of Cylindrical Concrete Specimens." Compressive strength, while not of primary importance in waste disposal, is an indication of waste form integrity. Compression test samples were cylinders with a diameter of two inches and four inches in length. After mixing, these samples were poured into their molds which were then placed into individual plastic bags to prevent evaporative water loss and were allowed to cure for seven days at $72^{\circ} \mathrm{F}$ before testing. The formulations tested correspond to the estimated minimum water compositions based on the minimum water/cement ratio and respective water/ash absorption ratios. Note that the required compressive strengths to insure a free standing solid are low, i.e., a waste form with a density of $130 \mathrm{lbs} / \mathrm{ft}^{3}\left(2.08 \mathrm{~g} / \mathrm{cm}^{3}\right)$ requires a minimum compressive strength of 0.71 psi per foot of waste form height.

The experimentally determined compressive strengths and densities of the formulations tested are listed in Table 5. The values given are the average measurements for triplicate samples of each formulation. The compressive strength and density of portland type I neat cement produced using a water/cement weight ratio of 0.3 is listed for comparison. The compressive strength is seen to generally decrease with increasing ash content in the formulation. The Battelle Northwest (BNW) TRU incinerator ash acts as 
Table 5

Compressive Strength of Solidified Waste Forms

(Seven-Day Cure Time).

\begin{tabular}{|c|c|c|c|c|c|c|}
\hline Ash Type & $\begin{array}{r}\text { Con } \\
\text { Ash } \\
\end{array}$ & $\begin{array}{l}\text { sition, } \\
\text { Cement }\end{array}$ & wt. & $\begin{array}{l}\% \\
\text { Water }\end{array}$ & $\begin{array}{l}\text { Density } \\
\mathrm{g} / \mathrm{cm}^{3} \\
\end{array}$ & $\begin{array}{l}\text { Compression Strength } \\
\text { psi } \pm \sigma\end{array}$ \\
\hline None & - & 76.9 & & 23.1 & 2.04 & $8010 \pm 740$ \\
\hline \multirow[t]{3}{*}{ BNW } & 55.0 & 26.2 & & 18.8 & 2.06 & $4060 \pm 640$ \\
\hline & 50.0 & 30.8 & & 19.2 & 2.07 & $5300 \pm 710$ \\
\hline & 40.0 & 40.0 & & 20.0 & 2.06 & $8010 \pm 1340$ \\
\hline \multirow[t]{3}{*}{ Rocky Flats } & 55.0 & 21.9 & & 23.1 & 2.02 & $132 \pm 38$ \\
\hline & 50.0 & 26.9 & & 23.1 & 2.04 & $259 \pm 73$ \\
\hline & 40.0 & 36.9 & & 23.1 & 1.98 & $530 \pm 177$ \\
\hline$\cdot \quad \cdot$ & & & & & & \\
\hline \multirow[t]{3}{*}{ Mound Lab } & 55.0 & 19.8 & & 25.2 & 2.03 & $126 \pm 41$ \\
\hline & 50.0 & 25.0 & & 25.0 & 2.03 & $191 \pm 25$ \\
\hline & 40.0 & 35.4 & & 24.6 & 2.04 & $222+35$ \\
\hline
\end{tabular}


an effective aggregate and produces waste form of high compressive strength. Incorporation of Rocky Flats plutonium recycle TRU ash and Mound Laboratory cyclone incinerator TRU ash $11 \mathrm{~A}^{2}$ results in waste forms of relatively low compressive strength. The ash content of these waste forms can be reduced to increase compressive strength, but as Table 5 shows, this increase is more pronounced with the Rocky flats ash waste. Note also that the densities of these waste forms are not greatly affected by the ash content. Little can currently be said to explain the large variation in compression strengths for waste forms containing different waste types. Both the Rocky Flats and Mound Lab wastes absorb significantly more water than the BNW ash and also appear to hold it more strongly producing a "clayey" consistancy. In addition, for a given waste form ash content, more water and hence less cement will be present in the formulation as the water/ash ratio is increased. The long set times for waste forms containing the Mound Lab waste suggests a possible interference with the cement hydration reaction. 


\section{Conclusions}

The simulated TRU incinerator ash wastes investigated can be' solidified with portland type I cement to produce acceptable waste forms. However, the compositional phase fields over which successful solidification occurs is limited because of the need to (I) provide sufficient water for a workable mixture, (2) prevent the occurrence of free standing water after solidification, and (3) furnish a sufficiently long set time. An adequate quantity of cement must also be present to bind the incinerator ash and form a monolithic solid, however, this was not found to be a limiting factor since the range of permissible water additions becomes increasingly narrow and hence the critical concernas the formulation cement content is decreased. The range of formulation water content is determined by both the quantity of cement present and the quantity and type of incinerator ash waste. All the wastes studied had appreciable but differing water absorption capacities, varying from 0.2 to 0.35 grams of water per gram of waste. The acceptable compositional phase fields decreased in area as ash wastes with higher water absorption capacities were considered. This decrease is in the direction of smaller permissible ranges of formulation water content and becomes increasingly evident for high ash content formulations. This behavior is due to the increased quantity of water required to produce mixture workability. Set time considerations impoșed formulational limitations only with the Battelle Northwest TRU incinerator ash waste, for which a maximum waste content of 55-60 percent by weight was determined. Maximum formulation waste contents of approximately 55 percent by weight were determined for the Rocky Flats plutonium recycle TRU ash and the Mound incinerator TRU ash $11 A^{2}$. For both of these wastes, the maximum formulation waste content was defined by the decrease in the permissible water content range with increasing waste additions.

The compression strengths of selected solidified waste form formulations were determined as an indication of waste form integrity. As expected, compression strengths decreased as the formulation ash waste content was increased and the cement content decreased. The compression strengths of the Battelle Northwest TRU incinerator ash waste forms were significantly higher than those of comparable formulations containing the other ash wastes. Waste forms containing the Rocky flats plutonium recycle TRU ash showed a more rapid rate of 
compression strength increase with decreasing waste content than did the other wastes. All formulations exhibited compression strengths far in excess of that required to produce a free standing monolithic solid of reasonable size.

This study has demonstrated that portland type I cement can be used to solidify the three simulated TRU incinerator ash wastes producing free standing monolithic waste forms with no associated free standing water. However, further work, which was not within the scope of the current study, should be performed to ascertain the suitability of these waste forms. Specifically, investigations should be conducted ito determine waste form leachability, mechanical properties, radiation stability (including potential for gas generation), thermal properties, and dispersibility. Without this information, a proper evaluation of cement waste forms incorporating TRU contaminated incinerator ash wastes cannot be made. 
